\title{
Alkaloids from Lime Flower (Tiliae flos) Exert Spasmodic Activity on Murine Airway Smooth Muscle Involving Acetylcholinesterase
}

\author{
Authors

\section{Affiliations} \\ 1 Institute of Pharmaceutical and Medicinal Chemistry, \\ Department of Pharmacology, University of Münster, \\ Münster, Germany \\ 2 Institute of Pharmaceutical Biology and Phytochemistry, \\ University of Münster, Münster, Germany
}

Alexander Hake ${ }^{1,2}$, Nico Symma ${ }^{2}$, Stefan Esch $^{2}$, Andreas Hensel $^{2}{ }^{\mathbb{D}}$, Martina Düfer $^{1}$ (D)

\section{ABSTRACT}

\section{Key words}

Tilia platyphyllos, Tilia cordata, Malvaceae, alkaloids, acetylcholinesterase inhibitor, tracheal smooth muscle

received accepted after revision published online

February 12, 2021

June 14, 2021

July 16, 2021

Bibliography

Planta Med 2022; 88: 639-649

DOI $10.1055 / a-1534-3766$

ISSN 0032-0943

(C) 2021. Thieme. All rights reserved.

Georg Thieme Verlag KG, Rüdigerstraße 14,

70469 Stuttgart, Germany

\section{Correspondence}

Prof. Dr. Martina Düfer

Institute of Pharmaceutical and Medicinal Chemistry,

Department of Pharmacology, University of Münster Corrensstraße 48, 48149 Münster, Germany

Phone: + 492518333339 , Fax: + 492518332144

martina.duefer@uni-muenster.de

Supplementary material is available under

https://doi.org/10.1055/a-1534-3766
Lime flower (Tiliae flos) is traditionally used either for treatment of the common cold or to relieve symptoms of mental stress. Recently, the presence of a new class of piperidine and dihydro-pyrrole alkaloids from lime flower has been described. The present study aimed to investigate the pharmacological activity of hydroacetonic lime flower extracts, alkaloid-enriched lime flower fractions, and isolated alkaloids on the murine airway smooth muscle and the cholinergic system. While a hydroacetonic lime flower extract did not show any pharmacological activity, enriched Tilia alkaloid fractions potentiated acetylcholine-induced contractions of the trachea by $\sim 30 \%$, showing characteristics comparable to galanthamine. Effects were abrogated by atropine, indicating an involvement of muscarinic receptors. The dihydro-pyrrole alkaloid tiliine $A$, the piperidine alkaloid tiliamine $B$, and the acetylated piperidine alkaloid tilacetine $A$ were characterized as acetylcholinesterase inhibitors. The positive control galanthamine $\left(\mathrm{IC}_{50}=2.0 \mu \mathrm{M}, 95 \% \mathrm{Cl} 1.7\right.$ to $\left.2.2 \mu \mathrm{M}\right)$ was approximately 100 times more potent compared to tiliine A $\left(\mathrm{IC}_{50}=237 \mu \mathrm{M}, 95 \% \mathrm{Cl} 207\right.$ to $\left.258 \mu \mathrm{M}\right)$ and tiliamine $\mathrm{B}$ $\left(\mathrm{IC}_{50}=172 \mu \mathrm{M}, 95 \% \mathrm{Cl} 158\right.$ to $\left.187 \mu \mathrm{M}\right)$. Neither DNA synthesis of HepG2 liver cells, HaCaT keratinocytes, and Caco-2 intestinal epithelial cells nor cell viability of primary human fibroblasts was reduced by the alkaloids. The indirect cholinergic activity of the alkaloids might explain some aspects of the traditional use of lime flowers and may extend the portfolio of compounds with regard to diseases involving parasympathetic malfunction or central cholinergic imbalance.

$\begin{array}{ll}\text { ABBREVIATIONS } \\ \text { ACh } & \text { acetylcholine } \\ \text { AChE } & \text { acetylcholinesterase } \\ \text { BrdU } & \text { 5-bromo-2'-deoxy-uridine } \\ \text { TE } & \text { Tilia extract } \\ \text { TF } & \text { Tilia fraction }\end{array}$

\section{ABBREVIATIONS}

ACh acetylcholine

AChE acetylcholinesterase

TE Tilia extract

\section{Introduction}

Since the Middle Ages, aqueous extracts from lime flower (Tiliae flos) have been used in Europe for treatment of the common cold due to diaphoretic properties [1]. The European Pharmacopoeia describes the flowers, including the bracts, from Tilia cordata MILL., Tilia platyphyllos SCOP., and Tilia vulgaris HEYNE (syn. Tilia europaea, a hybrid of both), Malvaceae, as well as their mixtures as raw materials for use as a herbal medicinal product [2]. Therapeutic use of lime flower preparations is specified by the Committee on Herbal Medicinal Products (HMPC) of the European Medi- 
cines Agency (EMA) for treatment of common cold symptoms as well as for relieving symptoms of mental stress [1]. Pharmacological data suggest that fractions from Tilia tomentosa show anxiolytic and sedative properties, which has been proven by plus-maze and hole-board tests [3]. Moreover, an extract from T. europaea inhibited muscimol binding in a specific binding assay and increased the ${ }^{36} \mathrm{Cl}^{-}$uptake in synaptoneurosomes, indicating a direct interaction with the $G_{A B A_{A}}$ receptor [4]. This effect might be caused by GABA [4] or by $\beta$-sitosterol and fatty acids, which were identified as the active compounds in T. americana [5]. In agreement with this, an orally administered extract from $T$. europaea exerted anxiolytic properties in mice [6]. In contrast, data addressing potential beneficial effects of lime flower preparations on symptoms of the common cold are heterogeneous and the mechanisms have not been adequately investigated until now. In folk medicine, diaphoresis has been strongly associated with a decrease in fever as a result of sweating, while an antispasmodic effect is assessed to be beneficial for curing cough symptoms [1]. Diaphoretic compounds in lime flower preparations have been suggested to be quercetin, kaempferol, and p-coumaric acid [1], but due to the limited bioavailability of quercetin and its glycosides after oral intake [7], and the wide distribution of these compounds in many other plants, it is rather unlikely that they indeed contribute to the claimed diaphoretic effects. Only limited information is available on the potential effects of Tilia extracts and isolated compounds concerning antispasmodic activity on the level of isolated tissue or whole organs. An antispasmodic effect on 5-HT-induced contractions on the rat ileum has been proven for an aqueous extract from $T$. europaea, while noradrenaline-induced contractions in the guinea pig aorta have not been abrogated [8]. The same extract neither affected ACh- nor histamineinduced contractions on the guinea pig ileum, but induced contractions that could be abolished by atropine [8]. Interestingly, the spasmodic, but not the antispasmodic effect, could be confirmed for dispersed intestinal smooth muscle cells by using an ethanolic extract from $T$. cordata [9]. Similar to the results described for ileal tissue, effects were antagonized by atropine [9]. Finally, it is discussed that polysaccharides as part of lime flower could reduce cough via bioadhesive layers on mucous membranes [10]. Due to the fact that in vitro experiments have shown contrary effects on smooth muscle without identifying any compounds responsible for spasmodic and antispasmodic effects and as adequate investigations on the lower respiratory tract are missing until now, the antispasmodic effect can be hardly transferred to treatment for cough.

The phytochemical composition of lime flower has been exhaustively investigated. Pharmaceutically relevant components are polysaccharides, predominantly acidic arabinogalactans [11]. Flavonoids, especially glycosides of kaempferol (e.g., astragalin, tiliroside) and quercetin (e.g., isoquercitrin, rutin, hyperosid), have been described, as already mentioned above [12-14]. Furthermore, volatile oil, containing monoterpenes (e.g., linalool, geraniol, 1,8-cineol) and phenylpropans (e.g., eugenol, anethol, 2-phenylethanol), contributes to the aromatic taste of lime flower extracts [14]. Other natural products in lime flower are oligomeric proanthocyanidins, mainly composed of catechin and epicatechin $[15,16]$. Additionally, organic acids (e.g., p-coumaric acid, caffeic acid), tocopherol, carbohydrates, saponins, amino acids, and hydroxylated coumarins can be found [1]. Recently, our group identified three series of each two diastereomeric alkaloids in hydroacetonic extracts of lime flower, namely, two 2-methyl-3,4-dihydro-2H-pyrrol-3-ols (tiliine $\mathrm{A}$ and $\mathrm{B}$ ), two 2-methyl-piperidin-3-ols (tiliamine $A$ and $B$ ), and two 3-O-acetylated 2-methyl-piperidin-3ol alkaloids (tilacetine A and B) [17]. Structural features of these unusual alkaloids are displayed in $>$ Fig. 1. Quantitative investigations revealed the presence of these alkaloids in hydroalcoholic extracts and in aqueous lime flower infusions also [17].

The present study investigated the potential pharmacological activity of Tilia extracts, enriched Tilia alkaloid fractions, and the isolated alkaloids. Pharmacological investigations were performed on isolated mouse tracheal slices by an AChE activity assay. In addition, in vitro toxicity regarding DNA synthesis of different cell lines was tested by BrdU incorporation assays and metabolic activity by MTT turnover.

\section{Results}

Lime flower herbal material was extracted with acetone/water $(7: 3 \mathrm{v} / \mathrm{v})$ and alkaloids were isolated and characterized as described in detail by Symma et al. [17]. After removal of the organic solvent, the aqueous solution was extracted with petroleum ether for removal of lipophilic compounds. The extract (TE) was fractionated by use of a cationic exchanger, yielding a basic fraction $\mathrm{TF}_{1}$, which was subsequently fractionated on Sephadex LH-20 [17]. This resulted in an alkaloid containing fraction $\mathrm{TF}_{2}$, which was subsequently purified in order to remove disturbing substances (e.g., the flavonoid linarin) by preparative HPLC on an RP18 stationary phase [17]. Thereby, the enriched Tilia alkaloid fraction $\mathrm{TF}_{3}$ was fractionated and the purified alkaloids $1 \mathrm{a}, \mathbf{2 b}$, and $3 a$ were isolated and quantified [17]. The fractionation scheme is displayed in Fig. 1S, Supporting Information.

TE was characterized by LC-(+)-ESI-qTOF-MS and peaks were assigned to known components of the genus Tilia by interpretation of MS, MS², and UV spectra ( $\bullet$ Table 1 and Fig. 2 c). The alkaloid containing fractions $\mathrm{TF}_{2}$ and $\mathrm{TF}_{3}$ were analyzed by HPLC-MS, indicating the presence of six different alkaloids, which had been identified as the dihydro-pyrrol alkaloid 1a (tiliine A), the piperidine alkaloid $2 \mathrm{~b}$ (tiliamine $\mathrm{B}$ ), and the acetylated piperidine alkaloid 3a (tilacetine A) and their corresponding diastereomeric forms ( $\triangleright$ Figs. 3 e and $\mathbf{4 d}$ ). As described by Symma et al. [17], all Tilia alkaloids of this fraction occur in two different diastereomeric forms, which are both cis-configurated at the positions 2 and 3 of the heterocycle. Until now, it is still unclear which absolute configuration can be attributed to which compound. For pharmacological tests, the alkaloids, which had been isolated in the highest amounts, were used, namely, tiliine A (1a), tiliamine B (2b), and tilacetine A (3a). The other diastereomers could not be tested due to low yields during isolation. Using a calibrated HPLC-MS method, the content of the alkaloids in the extract TE was determined as follows: 1 a $1.7 \mathrm{mg} / \mathrm{g}$ dry weight of the extract, $2 \mathrm{~b}$ $<0.1 \mathrm{mg} / \mathrm{g}$, and $3 \mathrm{a} 0.9 \mathrm{mg} / \mathrm{g}$.

For investigation of potential effects of the TE and the alkaloids, the mouse trachea was used as a model for the lower respiratory tract. The tissue bath experiments were performed with 


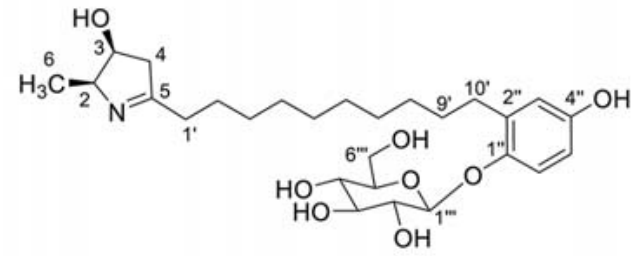

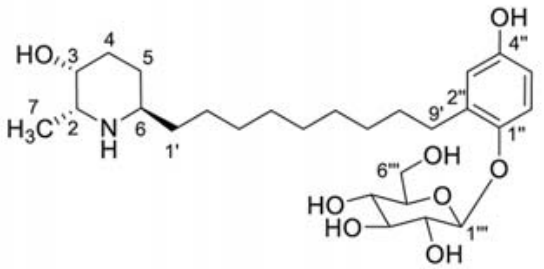

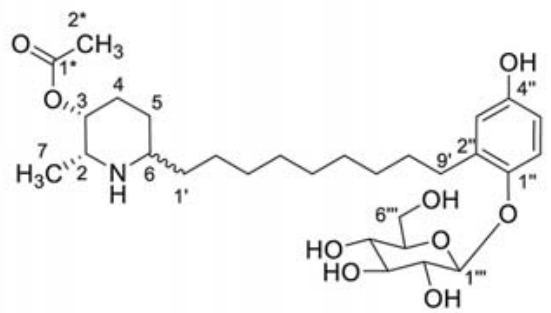

1a/1b

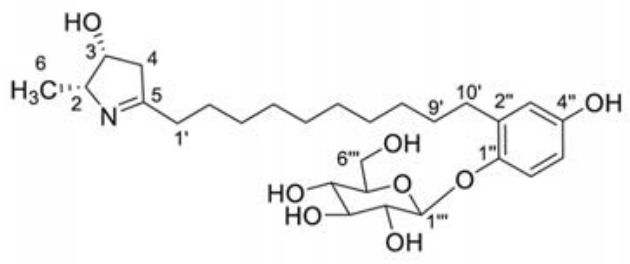

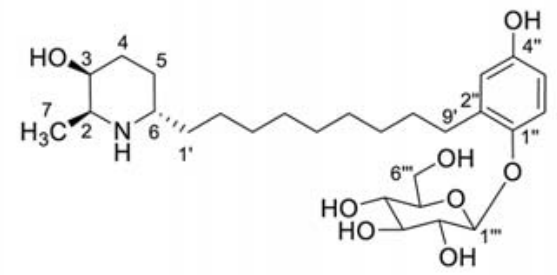

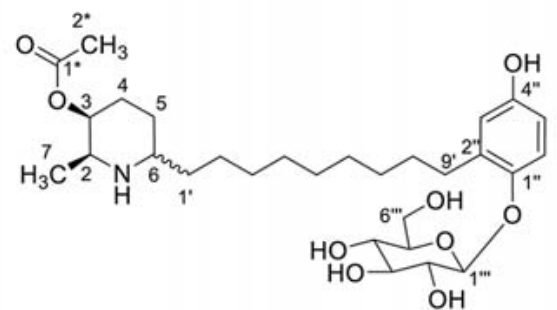

- Fig. 1 Structures of the investigated Tilia alkaloids tiliine A and B ( $1 a / 1 b)$, tiliamine A and B ( $2 a / 2 b)$, and tilacetine A and B (3a/3b) from lime flower [17]. The respective assignment to a or $b$ remains unknown.

the $\mathrm{TE}$ and enriched Tilia alkaloid fractions $\mathrm{TF}_{2}$ and $\mathrm{TF}_{3}$ containing tiliine A (1a), tiliamine B (2b), and tilacetine A (3a) ( Figs. 2-4). Even though it is possible to detect the alkaloids in the TE using a calibrated HPLC-MS method ( $1 \mathrm{mg} / \mathrm{mL}$ TE contains approximately $5 \mu \mathrm{M}$ tiliine $\mathrm{A}$ and $\mathrm{B}, 4 \mu \mathrm{M}$ tilacetine $\mathrm{A}$ and $\mathrm{B}$, and less than $1 \mu \mathrm{M}$ tiliamine $A$ and $B$, calculations were based on the HPLC-ESI-qTOF data reported in [17]), a 10-min pretreatment of isolated tracheal slices with $1 \mathrm{mg} / \mathrm{mL}$ TE did not affect the contraction maximum induced by $100 \mu \mathrm{M}$ ACh in the continued presence of TE ( $\vee$ Fig. 2 a, b: contraction force TE + ACh $88 \pm 16 \%$, related to the control with ACh, which was set to $100 \%$; $p>0.05$ ).

On the contrary, the enriched Tilia alkaloid fractions $\mathrm{TF}_{2}$ and $\mathrm{TF}_{3}$ significantly increased the ACh-induced contractions ( $\triangleright$ Figs. 3 and 4 ). After a 10-min pretreatment of the mouse trachea slices with $1 \mathrm{mg} / \mathrm{mL} \mathrm{TF}_{2}$, ACh $(100 \mu \mathrm{M})$ caused a significantly higher contraction compared to control experiments ( $\vee$ Fig. 3 a, b: contraction force $\mathrm{TF}_{2}+$ ACh: $129 \pm 8 \%$ compared to the control ACh alone: $100 \%$; $<0.05)$. Of note, an increase in the basal tone was observed during the pretreatment period. As this affected the contraction maximum, experiments were reevaluated after subtraction of the change in basal tone (contraction force $\mathrm{TF}_{2}+\mathrm{ACh}$ after subtraction of the alteration in basal tone: $114 \pm 2 \%$; $<0.001$ compared to ACh alone). In another series of experiments, $\mathrm{TF}_{2}(1 \mathrm{mg} / \mathrm{mL})$ was added to the precontracted tracheal slices 5 min after application of ACh $(100 \mu \mathrm{M})$. In this setup, the maximum force induced by ACh was acutely elevated.
( $\vee$ Fig. 3 c, d: contraction force $\mathrm{TF}_{2}$, minute 9-10, after adding ACh: $128 \pm 6 \%$, related to the contraction force in minute 4-5 after adding ACh). For the control, the time course of ACh-induced contractions without the addition of $\mathrm{TF}_{2}$ was analyzed in analogy (contraction force of the control minute 9-10 after adding ACh: $103.7 \pm 0.2 \%$, related to the contraction force in minute 4-5 after adding ACh; $\mathrm{p}<0.05$ vs. $\mathrm{TF}_{2}$-induced change). Reversibility was proven by application of ACh after washout of the test compound. The purity of $\mathrm{TF}_{2}$ was determined by UHPLC-DAD and the concentrations of alkaloids were roughly estimated from the chromatograms. In total, the alkaloids accounted for $18.3 \%$ of the peak area and, based on the single peak values, the concentrations of the diastereomers in $1 \mathrm{mg} / \mathrm{mL} \mathrm{TF}_{2}$ amounted to $35 \mu \mathrm{M}$ tiliine $A / B, 245 \mu \mathrm{M}$ tiliamine $A / B$, and $71 \mu \mathrm{M}$ tilacetine $A / B$. In order to investigate if the magnitude of the effect depends on the degree of ACh-induced concentrations, the tracheal slices were pretreated 10 min with a further purified alkaloid-enriched fraction $\left(\mathrm{TF}_{3}\right)$ of the $\mathrm{TE}$, and $\mathrm{ACh}$ was added in a cumulative manner $(1-200 \mu \mathrm{M})$ in the presence of this fraction ( $\vee$ Fig. 4 a). A contraction power induced by $200 \mu \mathrm{M}$ ACh was set as a $100 \%$ control. In these experiments, the purified fraction $\mathrm{TF}_{3}$ was chosen to make sure that the effect was not mediated by trace amounts of other compounds (e.g., linarin) found in $\mathrm{TF}_{2}$ ( $\triangleright$ Fig. 3 e, peak "L"). The concentration of the respective alkaloids in $0.1 \mathrm{mg} / \mathrm{mL} \mathrm{TF}_{3}$ (calculated by UHPLC-DAD) was $26 \mu \mathrm{M}$ for tiliine $\mathrm{A} / \mathrm{B}, 73 \mu \mathrm{M}$ for tiliamine $A / B$, and $17 \mu \mathrm{M}$ for tilacetine $A / B$. With this fraction $(0.1 \mathrm{mg} / \mathrm{mL})$, 


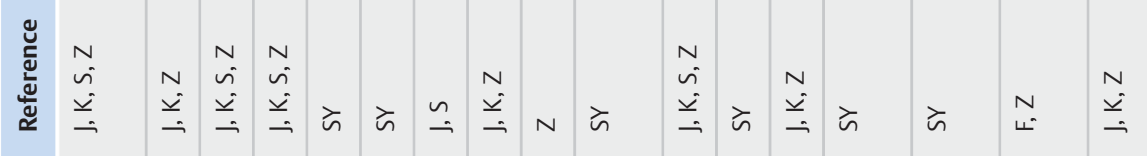

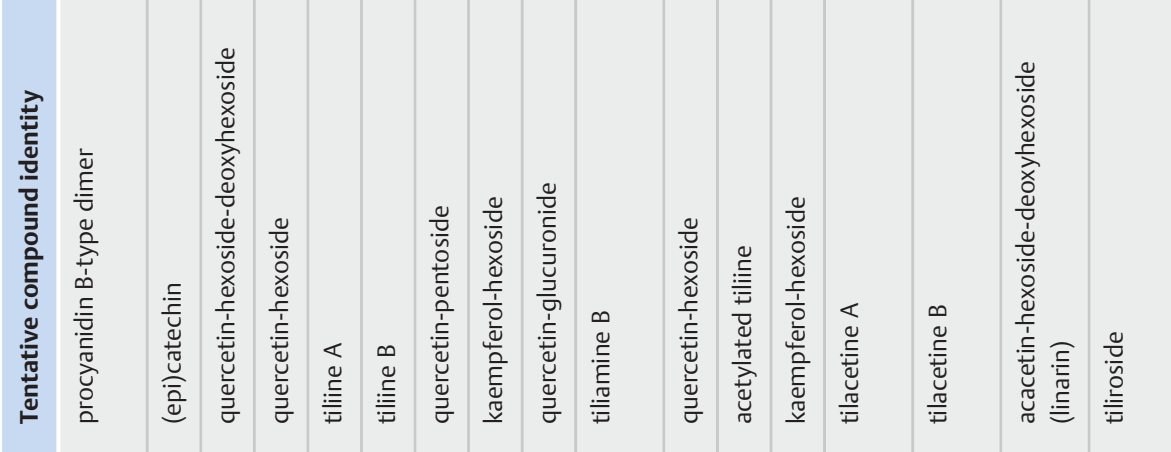

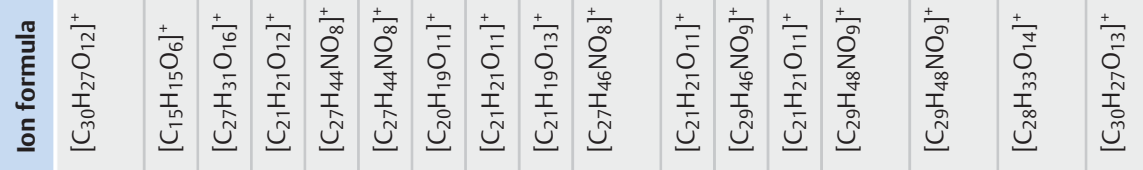

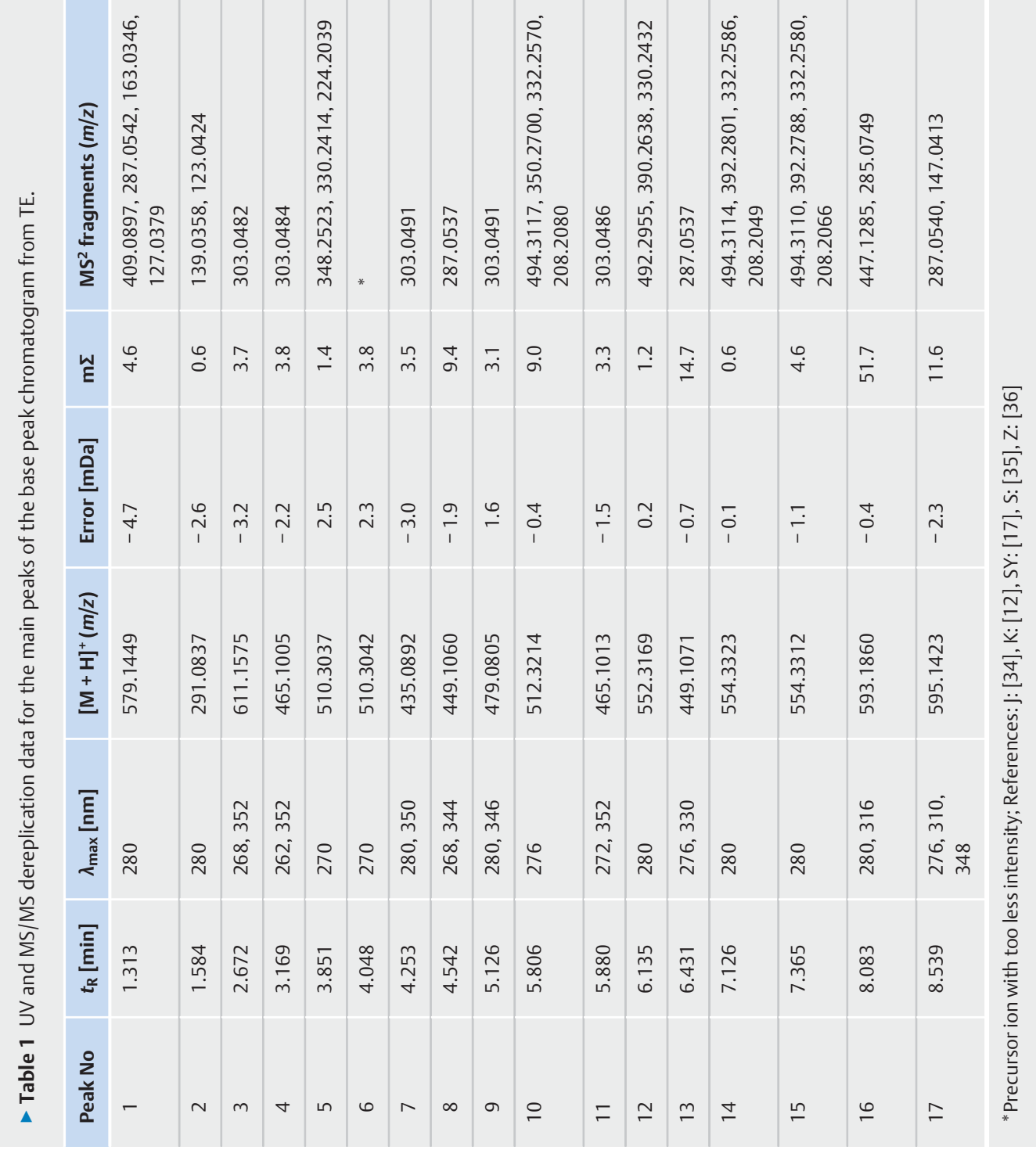




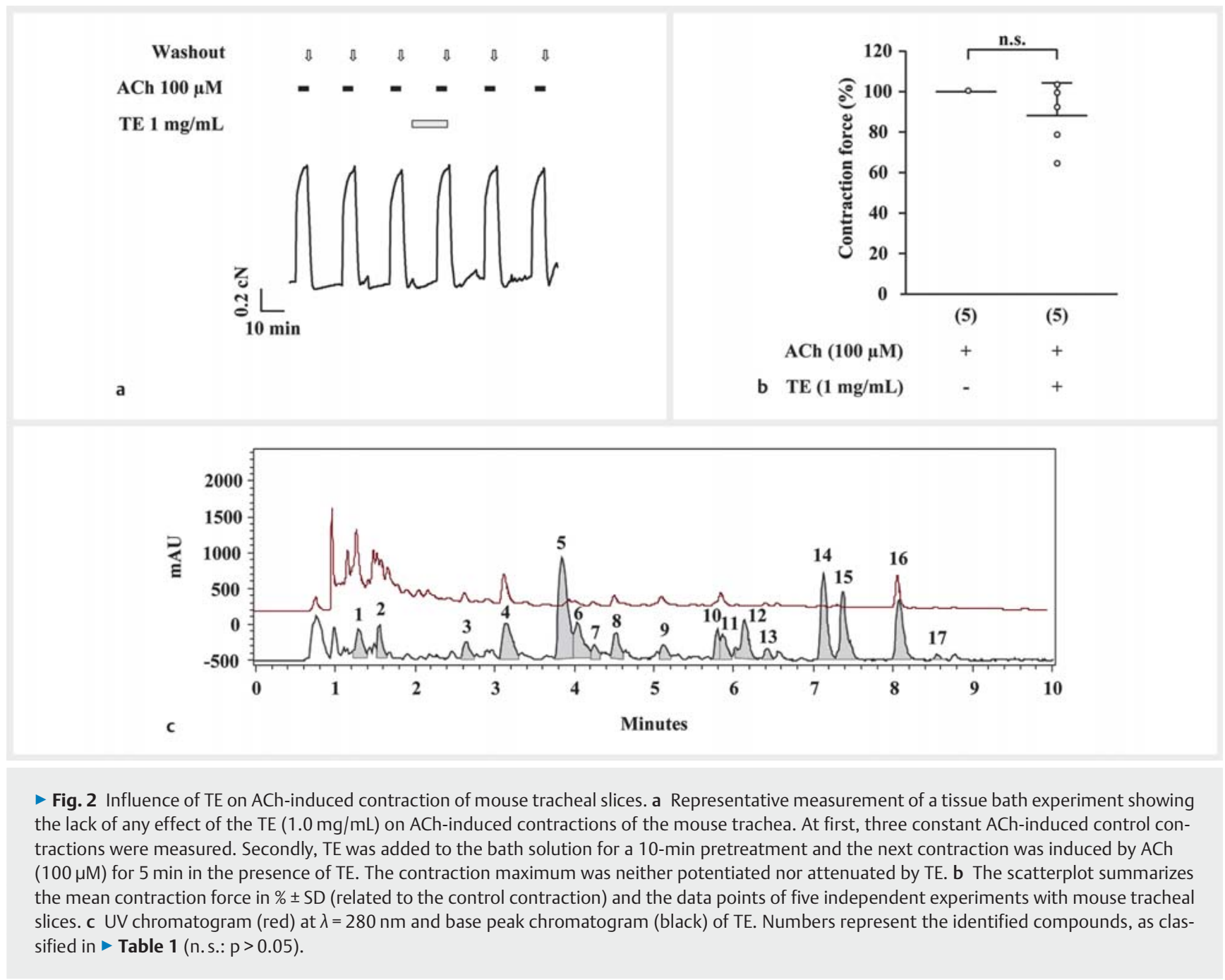

no effect on the basal tone was observed during the pretreatment period ( $\bullet$ Table 2 ). $\mathrm{TF}_{3}$ exhibited significantly stronger contractile responses compared to the control ( $\nabla$ Fig. $\mathbf{4 c}$ : contraction force $\mathrm{TF}_{3}+\mathrm{ACh} 10 \mu \mathrm{M}$ : $52 \pm 5 \%$ of the contraction obtained with $200 \mu \mathrm{M}$ ACh vs. control ACh $10 \mu \mathrm{M}$ : $38 \pm 1 \%$; $<0.05$; contraction force $\mathrm{TF}_{3}+100 \mu \mathrm{M}$ ACh: $103 \pm 6 \%$ vs. control ACh $100 \mu \mathrm{M}$ : $80 \pm 3 \% ; p<0.001)$. Up to now, our data clearly indicates that the alkaloid-enriched fractions of TE potentiate the effect of ACh. Galanthamine, a known inhibitor of AChE [18], was tested in the same manner in a concentration of $0.5 \mu \mathrm{M}$ ( $\bullet$ Fig. 4 b). This concentration was chosen because it did not significantly affect the basal tone ( $\vee$ Table 2 ). As expected, the AChE inhibitor potentiated the contractions induced by the exogenous application of ACh ( $\vee$ Fig. $\mathbf{4 b}, \mathbf{c})$. In the presence of atropine $(1 \mu \mathrm{M})$, all effects were abrogated and neither $\mathrm{TF}_{3}$ and galanthamine nor ACh led to any contractile response, as illustrated in representative example measurements ( $\triangleright$ Fig. 4 a, b).

To investigate whether AChE is a molecular target of the Tilia alkaloids, the three compounds $1 \mathrm{a}$ (tiliine A), $2 \mathrm{~b}$ (tiliamine B), and $3 a$ (tilacetine $A$ ) were tested for a potential influence on the AChE of Electrophorus electricus. The results indicate that the alka- loids $1 \mathrm{a}$ and $2 \mathrm{~b}$ are inhibitors of AChE (1a: $\mathrm{IC}_{50}=237 \mu \mathrm{M}, 95 \% \mathrm{Cl}$ 207 to $258 \mu \mathrm{M}, 2 \mathrm{~b}$ : IC $50=172 \mu \mathrm{M}, 95 \% \mathrm{Cl} 158$ to $187 \mu \mathrm{M})$, while the 3-O-acetylated tilacetine A was much less effective $(900 \mu \mathrm{M}$, 3a: $45 \pm 2 \%$ inhibition) ( $\mathbf{F i g} \mathbf{5 a}$ a). Galanthamine was approximately 100 times more potent compared to $1 \mathrm{a}$ and $2 \mathrm{~b}$ $\left(\mathrm{IC}_{50}=2.0 \mu \mathrm{M}, 95 \% \mathrm{Cl} 1.7\right.$ to $\left.2.2 \mu \mathrm{M}\right)$.

The effect of the test compounds $1 \mathrm{a}, 2 \mathrm{~b}$, and 3a on DNA synthesis of three cell lines, human liver cells (HepG2), human nontumorigenic keratinocytes ( $\mathrm{HaCaT}$ ), and human intestinal epithelial cells (Caco-2), was tested by a BrdU ELISA in order to investigate potential cell toxicity [19]. As displayed in $>$ Table 3, DNA synthesis of the alkaloid-treated cells $(1-100 \mu \mathrm{M}, 24 \mathrm{~h})$ was not significantly different to the respective untreated control groups, indicating the absence of antiproliferative toxic effects against the selected cell lines. In addition, Tilia alkaloids did not decrease metabolic activity, determined by a colorimetric MTT assay in primary human fibroblasts ( $\bullet$ Fig. $\mathbf{5}$ b). While tilacetine A turned out to slightly increase MTT turnover at a concentration of $100 \mu \mathrm{M}$, all other compounds did not significantly affect cell metabolism in both directions. 


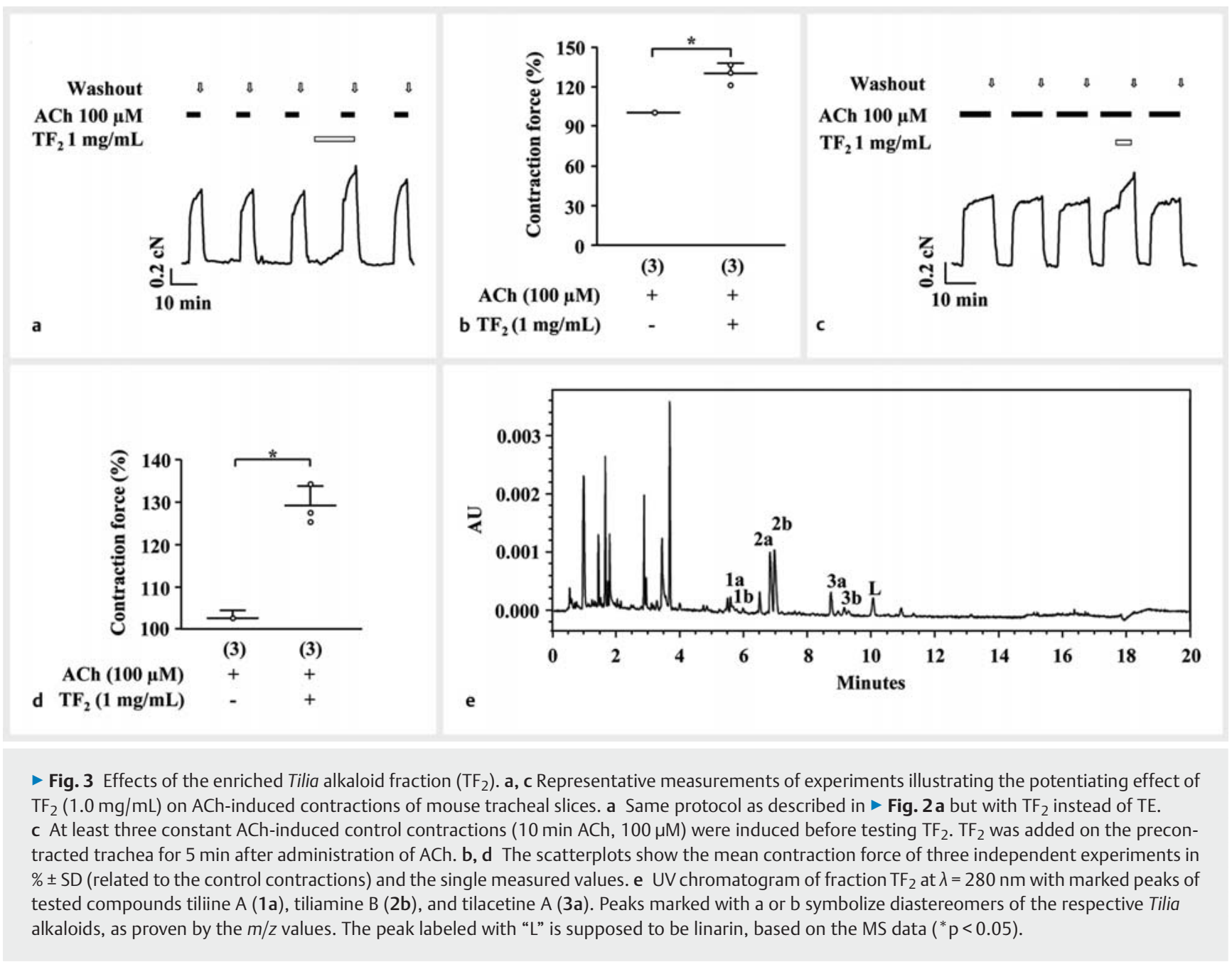

\section{Discussion}

The traditional use of Tiliae flos for the treatment of cough suggests relaxing effects on airway smooth muscle. Surprisingly, the TE turned out to have neither antispasmodic nor spasmolytic activities on murine airway smooth muscle ( $\bullet$ Fig. $\mathbf{2}$ a, b). Therefore, our findings provide no scientific evidence for using lime flower to treat cold symptoms via relaxation of the smooth muscle of the lower respiratory tract. On the contrary, the present study revealed that the fractions $\mathrm{TF}_{2}$ and $\mathrm{TF}_{3}$ contain spasmodic compounds, as both fractions potentiated the ACh-induced contractions ( $\vee$ Fig. $\mathbf{3}$ a, b and $\mathbf{4 a , c}$ ). Since the fraction $\mathrm{TF}_{2}$ contained traces of different natural compounds, experiments with the purified fraction $\left(\mathrm{TF}_{3}\right)$ were carried out. Fraction $\mathrm{TF}_{3}$ potentiated the ACh-induced contractions without increasing the basal tone ( $\vee$ Fig. 4a,c). Therefore, the idea that the Tilia alkaloids act as muscarinic agonists is rather unlikely. The mode of action is reversible and mediated through muscarinic receptors, as the contractions induced by the purified $\mathrm{TF}_{3}$ could be abrogated by atropine. In fact, the alkaloid-enriched fractions showed effects similar to galanthamine, giving reason to the hypothesis of an interaction with AChE. Linarin, a flavonoid that is part of $\mathrm{TE}$ and $\mathrm{TF}_{2}$
( $\vee$ Fig. 2c and Fig. 3e), has been reported to inhibit AChE [20], while it paradoxically exerts antispasmodic effects on uterine smooth muscle [21]. The results obtained in our study with the linarin-free fraction $\mathrm{TF}_{3}$ (as shown by LC-MS) clearly indicate that linarin was not necessary for the spasmodic effects ( $\vee$ Fig. 4 a, c, d). The present study demonstrated, for the first time, that the alkaloids tiliine $A$, tiliamine $B$, and tilacetine $A$ are inhibitors of AChE ( $\triangleright$ Fig. 5). This mode of action fits well with the results of our tissue bath experiments with functionally intact tracheal slices. The low amounts of Tilia alkaloids in TE $(<6 \mu \mathrm{M})$ is correlated to the lack of any effect of the hydroacetonic extract on airway smooth muscle contractility. The estimation of alkaloid content in the two fractions yielded a concentration of approximately $245 \mu \mathrm{M}$ tiliamine $\mathrm{A} / \mathrm{B}$ in $1 \mathrm{mg} / \mathrm{mL} \mathrm{TF}_{2}$. As tiliamine B inhibited more than $50 \%$ of the $A C h E$ in this concentration range, spasmodic effects mediated via AChE are suggested to result mainly from this compound. Tiliine (calculated concentration of $35 \mu \mathrm{M}$ ) is thought to act in synergy, while an involvement of tilacetine is rather unlikely. In the purified fraction $\mathrm{TF}_{3}$, the ratio of tiliamine to tiliine increased $(0.1 \mathrm{mg} / \mathrm{mL}: 73 \mu \mathrm{M}$ tiliamine $\mathrm{A} / \mathrm{B}$ and $26 \mu \mathrm{M}$ tiliine $A / B)$. The change in the ratio shifts the contribution of the single compounds and assuming that the effects are additive, AChE inhi- 


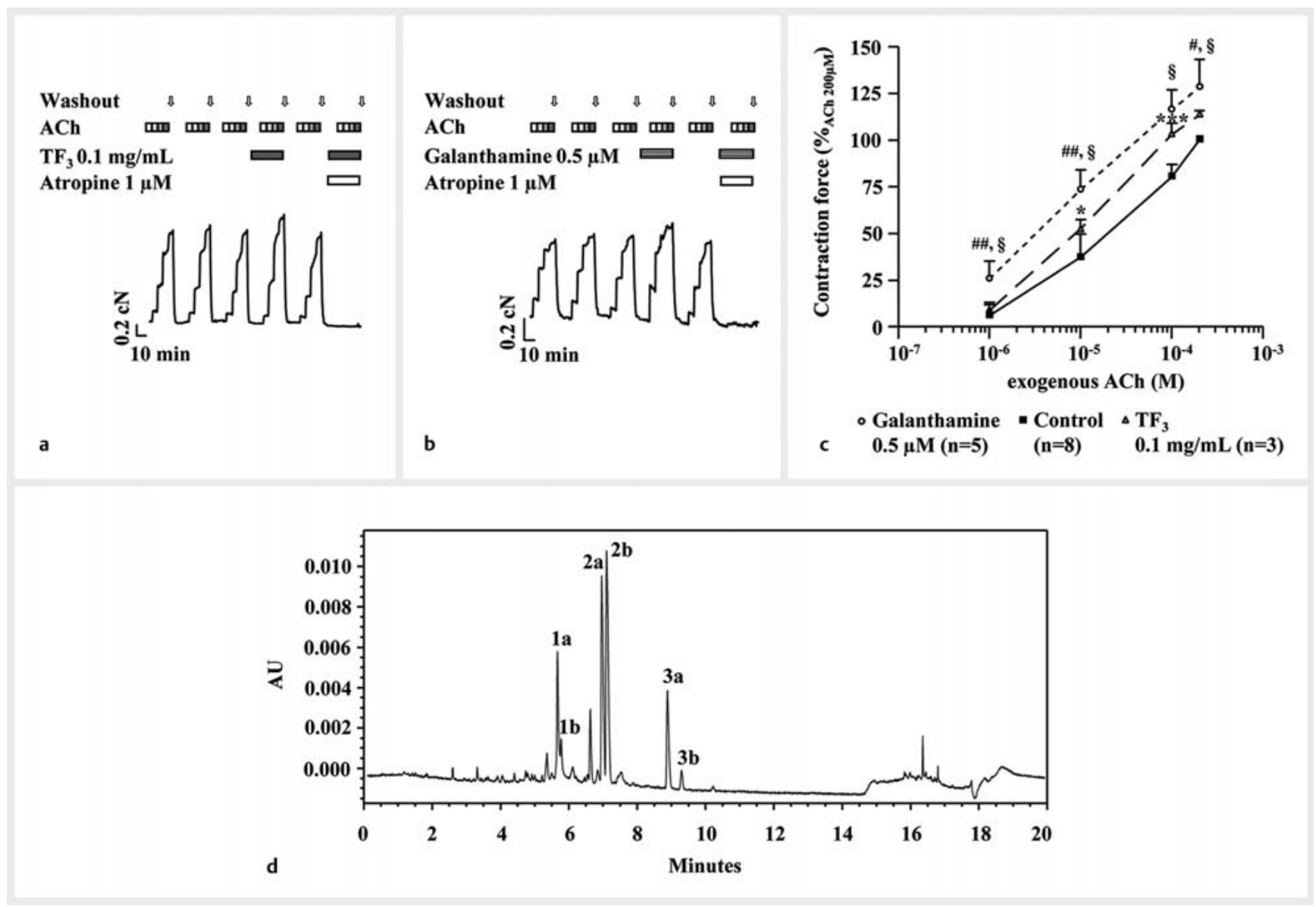

- Fig. 4 Investigation of a further purified fraction of the TE on tracheal contractions a, b Representative measurements of tissue bath experiments showing the potentiating effect of $\mathrm{TF}_{3}(0.1 \mathrm{mg} / \mathrm{mL})$ and galanthamine $(0.5 \mu \mathrm{M})$ on the contractile response induced by cumulatively added ACh $(1,10,100$, and $200 \mu \mathrm{M})$ as indicated by the horizontal bars. At least three ACh-induced control contractions were induced by stepwise elevation of ACh in 5-min intervals before the addition of the test compounds. After a pretreatment period of 10 min with $\mathrm{TF}_{3}$ (a) or galanthamine (b) ACh was increased again. Data was normalized to the effect of $200 \mu \mathrm{M}$ ACh in each experiment. c The data shown represents the mean of three $\left(\mathrm{TF}_{3}\right)$ or five (galanthamine) independent experiments and the respective controls $(n=8)$. d UV chromatogram at $280 \mathrm{~nm}$ of fraction $\mathrm{TF}_{3}$ with marked peaks of tested compounds tiliine A (1a), tiliamine B (2b), and tilacetine A (3a). Peaks marked with a or b symbolize diastereomers of the respective Tilia alkaloids, as proven by the $\mathrm{m} / \mathrm{z}$ values. ${ }^{\circledR} \mathrm{P}<0.001 \mathrm{vs}$. control, ${ }^{* * *} \mathrm{p}<0.001 \mathrm{vs}$. control, ${ }^{*} \mathrm{p}<0.05$ vs. control, ${ }^{\# \#} \mathrm{p}<0.01 \mathrm{vs}$. $\mathrm{TF}_{3}$ $0.1 \mathrm{mg} / \mathrm{mL},{ }^{\#} \mathrm{p}<0.05$ vs. $\mathrm{TF}_{3} 0.1 \mathrm{mg} / \mathrm{mL}$.

- Table 2 Influence of $\mathrm{TF}_{3}$ and galanthamine $(0.5$ and $1 \mu \mathrm{M})$ on the basal tone.

Contraction force (\%)

\begin{tabular}{|l|l|l|l|}
\hline Control & $\mathrm{TF}_{\mathbf{3}}(\mathbf{0 . 1} \mathbf{~ m g} / \mathbf{m L})$ & Galanthamine $(\mathbf{0 . 5} \boldsymbol{\mu M})$ & Galanthamine $(\mathbf{1} \boldsymbol{\mu M})$ \\
\hline$-1 \pm 1$ & $0 \pm 1$ & $5 \pm 10$ & $21 \pm 18^{* * *, \#, \S}$ \\
\hline
\end{tabular}

The data listed in the table represents the mean contraction force in $\% \pm S D$ of three $\left(\mathrm{TF}_{3}\right)$ and five (galanthamine 0.5 and $1 \mu \mathrm{M}$ ) independent experiments and the respective controls $(n=13)$. Data was normalized to the effect of $A C h(200 \mu M)$ in the absence of test compounds. ${ }^{* * *} P<0.001$ vs. control, ${ }^{\#} p<0.05$ vs. galanthamine $0.5 \mu \mathrm{M},{ }^{\S} \mathrm{p}<0.05 \mathrm{vs}$. $\mathrm{TF}_{3} 0.1 \mathrm{mg} / \mathrm{mL}$

bition would be around $40 \%$. The effect on the basal tone observed in response to $1 \mathrm{mg} / \mathrm{mL} \mathrm{TF}_{2}$ is in agreement with reports for galanthamine [22] and might result from a reduced degradation of endogenous ACh release within the organ sample. However, we cannot exclude other targets that are addressed by the newly characterized alkaloids, e.g., improved receptor sensitivity to ACh or effects on intracellular signaling pathways. Interestingly, our data show that the acetylation of the 3-hydroxy-substituted piperidine ring decreased the inhibition potency, suggesting that the piperidine heterocyclus of the molecule seems to be the func- 


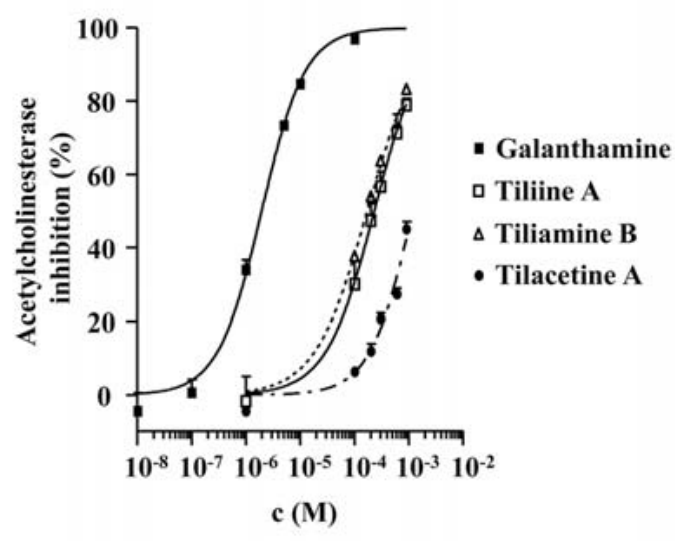

a

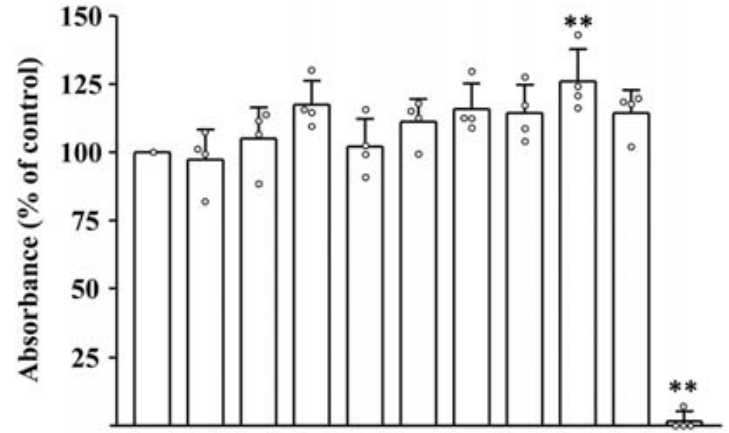

(4) (4) (4) (4) (4) (4) (4) (4) (4) (4) (4)

Tiliine A $(\mu \mathrm{M}) \quad-\quad 30010010 \quad-\quad-\quad-\quad-\quad-\quad-$

Tiliamine B $(\mu \mathrm{M}) \quad-\quad-\quad-\quad-30010010-\quad-\quad-$

Tilacetine A $(\mu \mathrm{M}) \quad-\quad-\quad-\quad-\quad-\quad-\quad-30010010 \quad-$

b

- Fig. 5 a Inhibitory influence of Tilia alkaloids on AChE. The values represent the mean inhibition (\% \pm SD) of the AChE by different test compounds as indicated in the diagram. Samples were measured in triplicate. b Effect of Tilia alkaloids on metabolic activity of primary human fibroblasts. MTT reduction was determined after incubation with the indicated concentrations of the Tilia alkaloids for $24 \mathrm{~h}$. The scatterplot illustrates the mean \pm SD of four independent experiments and the single data points; ${ }^{* *} \mathrm{p}<0.01 \mathrm{vs}$. control.

- Table 3 Influence of Tilia alkaloids tiliine A (1a), tiliamine B (2b), and tilacetine A (3a) on the DNA synthesis (\%, related to the untreated control) of HepG2, HaCaT, and Caco-2 cells after $24 \mathrm{~h}$ of incubation as determined by BrdU incorporation ELISA.

\begin{tabular}{|c|c|c|c|c|c|c|c|c|c|}
\hline & \multicolumn{3}{|c|}{ HepG2 (\%) } & \multicolumn{3}{|c|}{ НаСат (\%) } & \multicolumn{3}{|c|}{ Caco-2 (\%) } \\
\hline & $100 \mu \mathrm{M}$ & $10 \mu \mathrm{M}$ & $1 \mu \mathrm{M}$ & $100 \mu \mathrm{M}$ & $10 \mu \mathrm{M}$ & $1 \mu \mathrm{M}$ & $100 \mu \mathrm{M}$ & $10 \mu \mathrm{M}$ & $1 \mu \mathrm{M}$ \\
\hline Tiliine A (1a) & $94 \pm 9$ & $93 \pm 9$ & $91 \pm 7$ & $103 \pm 3$ & $100 \pm 1$ & $98.9 \pm 0.8$ & $100 \pm 5$ & $101 \pm 3$ & $101 \pm 3$ \\
\hline Tiliamine B (2b) & $97 \pm 10$ & $91 \pm 5$ & $92 \pm 12$ & $100 \pm 4$ & $100 \pm 2$ & $102 \pm 5$ & $102 \pm 4$ & $102 \pm 5$ & $100 \pm 4$ \\
\hline Tilacetine A (3a) & $94 \pm 6$ & $94 \pm 8$ & $94 \pm 6$ & $101 \pm 3$ & $100 \pm 7$ & $101 \pm 4$ & $107 \pm 8$ & $105 \pm 5$ & $104 \pm 7$ \\
\hline DMSO 10\% & \multicolumn{3}{|c|}{$27.6 \pm 0.5^{\#}$} & \multicolumn{3}{|l|}{$45 \pm 6^{* *}$} & \multicolumn{3}{|l|}{$32 \pm 2^{* *}$} \\
\hline
\end{tabular}

The values represent the mean \pm SD from three independent experiments with two to three technical replicates ( ${ }^{\circ}$ one independent experiment with two to three technical replicates). Test groups with supplementation of DMSO served as a positive control; ${ }^{* *} \mathrm{p}<0.01 \mathrm{vs}$. control

tional group responsible for targeting AChE. This hypothesis might be supported by data reported for other piperidine-containing compounds. Hydroxy-methyl-substituted alkyl-piperidine alkaloids from Senna spectabilis have been shown to be AChE inhibitors [23]. Furthermore, the piperidine alkaloid juliflorine has also been described as a potent inhibitor of AChE [24]. To the best of our knowledge, this is the first time that an AChE inhibition is reported for 2-methyl-3,4-dihydro-2H-pyrrol-3-ol derivatives. The impact of the glycosylation of the alkaloids remains unclear at the present stage. Future experiments should clarify if glycosylation influences the permeation over barrier membranes and if the sugar moiety influences the AChE inhibitory activity. No negative influence of the test compounds has been observed against HepG2, HaCaT, and Caco-2 cell lines with respect to BrdU incorporation. This might be a promising hint, especially concerning liver cells, as, e.g., tacrine, the prototype of AChE inhibitors for treating Alzheimer's disease, was withdrawn from the market due to pronounced liver toxicity [25]. The MTT assay with primary human fibroblasts further supports that the alkaloids do not im- pair cell function or viability. The reason for the significantly higher level of MTT turnover observed with $100 \mu \mathrm{M}$ tilacetine $\mathrm{A}$ is unclear. As it was not concentration dependent, it most likely results from incidental variations in the cell population and not from targeted induction of cell proliferation. For lime flower, no toxicity studies have been published, until now, and the herbal medicinal material is generally regarded as nontoxic.

The results reported are interesting in respect to two aspects. First, the AChE inhibition and the subsequent activation of muscarinic signaling pathways by the alkaloids can contribute to the understanding of the traditional use of lime flower extracts as a diaphoretic agent. Local inhibition of AChE was reported to increase the sweat rate in human volunteers [26], and hyperhidrosis was described for licensed AChE inhibitors [27]. Not only Tilia extracts, but also herbal teas contain Tilia alkaloids [17]. Proposed sudatory infusions include two cups of lime flower tea $(4 \mathrm{~g}$ of herbal material per cup) [1], resulting in an intake of approximately $1.5 \mathrm{mg}$ of Tilia alkaloids. Dependent on their pharmacokinetic properties, the alkaloids might contribute to diaphoresis to- 
gether with heat-induced effects. Secondly, one can consider a chance for new indication areas for formulations with standardized and sufficiently high alkaloid content. Peripheral reduction of AChE activity was suggested for treatment of urinary retention or myasthenia gravis $[28,29]$. In case of sufficient delivery across the blood-brain barrier, the alkaloids might extend the spectrum of drugs used for therapy of central dysfunction of the cholinergic system, e.g., early stages of Alzheimer's disease or other forms of cognitive decline.

Future experiments should focus on intestinal absorption, metabolism, and the ability of the compounds to cross the bloodbrain barrier. There is evidence that the alkaloids found in lime flower can function as hydrophilic prodrugs due to their phenolglycoside moiety being absorbed via the duodenal $\mathrm{Na}^{+} /$glucose carrier [30]. These glycosides might be subsequently activated by deglycosylation, as has been reported for arbutin, for which the pharmacokinetics is already characterized [31].

In summary, the present study reveals the pharmacological activity of the Tilia alkaloids on AChE and mouse trachea. The traditional use of lime flower might comprise such mechanisms. In addition, our findings provide new perspectives for the potential benefit of lime flower preparations with a standardized alkaloid content.

\section{Materials and Methods}

\section{Plant material - extraction and isolation}

Lime flower plant material was collected on June 16 and July 2, 2019, at the Medicinal Plant Botanical Garden of the University of Münster (Germany, 51 57'54.5' 'N 7³6'24.4' 'E) and identified as T. platyphyllos SCOP. and T. cordata MILL. by A.H. and N.S. Voucher specimens (IPBP 512, IPBP 513) are deposited at the archives of the Institute of Pharmaceutical Biology and Phytochemistry (Münster, Germany). As described in Symma et al. [17] in detail, the dried and cut herbal mixture of $T$. platyphyllos and T. cordata $(1.3 \mathrm{~kg})$ was extracted in aliquots of $100 \mathrm{~g}(2 \times 1000 \mathrm{~mL})$ with a mixture of cold acetone/water ( $7: 3 \mathrm{v} / \mathrm{v}$ ) (Fig. 1S, Supporting Information). After removal of acetone under vacuo, the aqueous phase was extracted with petroleum ether $(5 \times 600 \mathrm{~mL}$ for each extraction step) to remove lipophilic compounds, resulting in $225 \mathrm{~g}(17 \% \mathrm{w} / \mathrm{w}$, related to the starting material) of TE. The isolation of Tilia alkaloids was carried out by different fractionation steps using cationic exchange Sephadex LH-20 chromatography and preparative HPLC on an RP18 stationary phase as reported in Symma et al. [17]. Six alkaloids have been isolated and identified, representing three pairs of diastereomers. The absolute stereochemistry has not been identified yet [17]. The diastereomers tested were tiliine A (1a), tiliamine B (2b), and tilacetine A (3a).

\section{Chemicals, reagents, cell lines}

All solvents were of analytical quality and obtained from VWR International. ACh chloride (purity $>99 \%$ ) was purchased from Sigma-Aldrich. Atropine (purity $>99 \%$ ) was obtained from TCl Chemicals. Galanthamine (purity $>99 \%$ ) was kindly provided by Janssen-Cilag. Cell lines used: HepG2 (ATCC HB-8065, clone H20) was obtained from Prof. Mersch-Sundermann, Freiburg, Germany,
HaCaT (ATCC CCL-17) was a friendly gift from Prof. Fusenig, Heidelberg, Germany to A.H., and CaCo-2 cells (ATCC HTB-37, ACC 169) were kindly provided by Prof. Langer, Münster, Germany. Primary human normal dermal fibroblasts were resected from human foreskins, which were kindly provided by the University Hospital of Münster, Germany.

\section{Animals and preparation of mouse tracheal slices}

Male and female C57BL/6 N mice [Charles River and own breeding (Institute of Pharmaceutical and Medicinal Chemistry, University of Münster, Germany)] were housed under standard conditions. Animal care followed the rules of German laws (Az. 53.5.32.7.1/ MS-12668, December, 4, 2018, Health and Veterinary Office Münster, Germany). The mice were sacrificed using $\mathrm{CO}_{2}$. After removing surrounding tissue, the trachea was excised, cut into $3 \mathrm{~mm}$ slices, and stored in Krebs-Henseleit buffer at 4 to $8^{\circ} \mathrm{C}$ until the experiments started.

\section{Tissue bath experiments}

Experiments were performed by the use of $3 \mathrm{~mm}$ tracheal slices in a Mayflower Horizontal Tissue Bath (Hugo Sachs Elektronik). Tracheal slices were placed between the hooks of the 5-mL tissue bath chamber containing Krebs-Henseleit buffer (in $\mathrm{mM}: \mathrm{NaCl}$ 118.1, $\mathrm{KCl}$ 4.7, $\mathrm{CaCl}_{2} 2.5, \mathrm{MgSO}_{4}$ 1.2, $\mathrm{KH}_{2} \mathrm{PO}_{4}$ 1.2, $\mathrm{NaHCO}_{3} 25$, glucose 5.6, $\mathrm{pH}$ of 7.4 , and temperature of $37^{\circ} \mathrm{C}$ ). Each slice was adjusted to a preload of $0.2 \mathrm{cN}$. After an equilibration time of $60 \mathrm{~min}$, the experiments were started. During an experiment, the buffer was constantly gassed with carbogen $\left(95: 5 \%, \mathrm{O}_{2}\right.$ : $\mathrm{CO}_{2}$ ). The contraction force was measured isometrically every $2 \mathrm{~s}$ by using a force transducer (F10 Type 375), an amplifier (TAM-A Type 705/1), and evaluation software (HSE ACAD 2.0). Contractions induced by $A C h$ reached a steady state within 5 min. In the experiments with $100 \mu \mathrm{M}$ ACh, the last contraction of the three succeeding contraction controls was used as the $100 \%$ control and test solutions were added 10 min before and during the next 5-minute bolus of ACh. When the effect on top of the contraction maximum of $100 \mu \mathrm{M}$ ACh was investigated, the last contraction before the addition of the test compound was used as a control, the contraction in minute 4-5 after adding ACh was set to $100 \%$, and substances (treatment time of $5 \mathrm{~min}$ ) and controls were evaluated in minute 9-10 after the addition of ACh. In the experiments in which ACh was added in a cumulative manner (every $5 \mathrm{~min}$ ), the averaged data of the last three ACh-induced control contractions were taken as a control and the contraction force at a concentration of $200 \mu \mathrm{M}$ ACh was set as $100 \%$. Test compounds were present $10 \mathrm{~min}$ before and during the stepwise elevation of ACh.

\section{Phytochemical characterization of Tilia extract}

UHPLC-ESI-qTOF-MS analysis was performed using a Dionex Ultimate 3000 RS Liquid Chromatography System with a Waters Acquity UPLC BEH C18 $(2.1 \times 100 \mathrm{~mm}, 1.7 \mu \mathrm{m})$ column at a temperature of $40^{\circ} \mathrm{C}$. The injection volume was $10 \mu \mathrm{L}$ and the flow rate was $0.4 \mathrm{~mL} / \mathrm{min}$. Samples were dissolved in methanol/water $(1: 9 \mathrm{v} / \mathrm{v})$ at a concentration of $10 \mathrm{mg} / \mathrm{mL}$. The binary gradient was comprised of (A) water with $0.1 \%$ formic acid and (B) acetonitrile with $0.1 \%$ formic acid. Gradient $t_{R}: 0.00$ to 9.00 min linear 
from 15\% B initially to $38 \%$ B; 9.00 to 9.02 min linear from 38 to $100 \% \mathrm{~B} ; 9.02$ to $15.00 \mathrm{~min}$ isocratic at $100 \% \mathrm{~B} ; 15.00$ to $15.10 \mathrm{~min}$ linear from 100 to $15 \% \mathrm{~B} ; 15.10$ to $20.00 \mathrm{~min}$ isocratic equilibration at $15 \% \mathrm{~B}$. Eluted compounds were detected using a Dionex Ultimate DAD-3000 RS over a wavelength range of $\lambda=200$ to $400 \mathrm{~nm}$ and a Bruker Daltonics micrOTOF-QII time-of-flight mass spectrometer equipped with an Apollo electrospray ionization source in the positive mode at $3 \mathrm{~Hz}$ over a mass range of $\mathrm{m} / \mathrm{z} 50$ 1500 using the following instrument settings: nebulizer gas nitrogen: 3.0 bar; dry gas nitrogen: $9 \mathrm{~L} / \mathrm{min}, 200^{\circ} \mathrm{C}$; capillary voltage: $4500 \mathrm{~V}$; end plate offset: $500 \mathrm{~V}$; transfer time: $100 \mu \mathrm{s}$, prepulse storage: $6 \mu \mathrm{s}$, collision energy: $8 \mathrm{eV}$. MS/MS scans were triggered by AutoMS2 settings within a range of $\mathrm{m} / \mathrm{z} 50-1500$ using a collision energy of $40 \mathrm{eV}$ and collision cell RF of $130 \mathrm{Vpp}$. The UV chromatogram at $280 \mathrm{~nm}$ and the base peak chromatogram of TE are

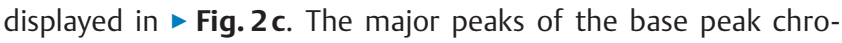
matogram were identified by comparison of the $\mathrm{m} / \mathrm{z}$ values from the $[\mathrm{M}+\mathrm{H}]^{+}$ion and the respective $\mathrm{MS}^{2}$ spectra with the respective data sets from the literature ( $\bullet$ Table 1 ).

\section{UHPLC-PDA analysis}

Fractions $\mathrm{TF}_{2}$ and $\mathrm{TF}_{3}$ were analyzed via a Waters Acquity UPLC system on an Acquity UPLC HSS T3 $(1.8 \mu \mathrm{m}, 2.1 \times 100 \mathrm{~mm})$ stationary phase (Waters). Mobile phase: (A) water with formic acid $0.1 \%$; (B) acetonitrile with $0.1 \%$ formic acid. The gradient was designed as follows: $t_{R} 0$ to 4 min: linear from 0 to $18 \% \mathrm{~B} ; 4$ to 14 min: 18 to $30 \% \mathrm{~B} ; 14$ to $16 \mathrm{~min}: 30$ to $100 \% \mathrm{~B} ; 16$ to $17 \mathrm{~min}$ : isocratic at $100 \% \mathrm{~B} ; 17$ to $18 \mathrm{~min}$ : 100 to $0 \% \mathrm{~B}$; 18 to $20 \mathrm{~min}$ : isocratic at $0 \% \mathrm{~B}$. The column temperature was $40{ }^{\circ} \mathrm{C}$, the flow rate was $0.5 \mathrm{~mL} / \mathrm{min}$, and the injection volume was $4 \mu \mathrm{L}$. $\mathrm{TF}_{2}$ and $\mathrm{TF}_{3}$ were solved in water at a concentration of $0.10 \mathrm{mg} / \mathrm{mL}$ and $0.25 \mathrm{mg} / \mathrm{mL}$, respectively. Eluted compounds were detected using a Waters PDA e $\lambda$ over a wavelength range of $\lambda=200$ to $800 \mathrm{~nm}$ and a Waters QDa mass spectrometer in the positive ion mode with a cone voltage of $15 \mathrm{~V}$ and a capillary voltage of $0.8 \mathrm{~V}$. The respective UV chromatograms at $280 \mathrm{~nm}$ are displayed in - Figs. $\mathbf{3 e}$ and $\mathbf{4 d}$. The purity of the alkaloid-enriched fractions $\left(\mathrm{TF}_{2}\right.$ and $\mathrm{TF}_{3}$ ) was determined at $\lambda=280 \mathrm{~nm}$ and thereby the concentrations of the alkaloids were calculated.

\section{5-Bromo-2'-deoxy-uridine incorporation assay and MTT assay}

For determination of DNA synthesis, the BrdU labeling and detection kit III (Roche Diagnostics) was used according to the manufacturer's instructions based on a method described by Porstmann et al. [19]. The influence of the test compounds on BrdU incorporation was investigated in Hep-G2 (ACC 180), HaCaT (ATCC CCL-17), and CaCo-2 cells (ACC 169). After a 24-hour incubation with 1,10 , or $100 \mu \mathrm{M}$ of the alkaloids in DMEM [high glucose, supplemented with fetal calf serum $10 \%$ (Biochrom), nonessential amino acids $1 \%$ (Sigma-Aldrich), and penicillin/streptomycin 1\% (Biochrom)] at $35^{\circ} \mathrm{C} / 5 \% \mathrm{CO}_{2}, 50000-70000$ cells/well were transferred into a 96-well plate. Cell viability ( $\geq 80 \%)$ was determined by a CASY cell counter model TT (Roche Innovatis). The number of independent assays was $n=3$ per cell line with 23 technical replicates. Cultivation media, supplemented with $10 \%$ DMSO, served as a toxicity control.
The MTT assay was performed according to the protocol of Mosmann [32]. The influence of the alkaloids (10, 100, and $300 \mu \mathrm{M})$ on MTT turnover was analyzed in human dermal fibroblasts. After culture of the fibroblasts with the test compounds for $24 \mathrm{~h}$ and the addition of MTT for $4 \mathrm{~h}$, the formazan was dissolved in DMSO and detected photometrically. The number of independent assays was $n=4$ with 7-8 technical replicates for the untreated samples and the toxicity control (DMSO 10\%) and 4 technical replicates for the test compounds.

\section{Acetylcholinesterase inhibitor assay}

The AChE inhibitor screening kit and the purified AChE of E. electricus were obtained from Sigma-Aldrich and used according to the manufacturer's instructions. All samples contained the same amount of DMSO (1\%). The AChE assay is based on the Ellman's method [33]. The colored product (5-thio-2-nitrobenzoic acid) formed by the active AChE was quantified at $t_{0 \text { min }}$ and $t_{10 \text { min }}$ after the addition of the reaction mix by the measurement at $\lambda=412 \mathrm{~nm}$ in a plate reader (CLARIOstar, BMG Labtech). The IC 50 values were calculated by fitting sigmoidal dose-response curves with the variable slope using GraphPad Prism version 3.00 for Windows (GraphPad Software).

\section{Statistics}

All tissue bath experiments were carried out with tracheal slices of at least three different mouse preparations. The results represent the means $\pm S D$. For comparing two different conditions, a twotailed paired Student's t-test was performed and for multiple comparisons, ANOVA (analysis of variance) followed by StudentNewman-Keul's post hoc test was performed. In cell assays for multiple comparisons, ANOVA (analysis of variance) followed by Dunnett's post hoc test was performed. GraphPad Prism Windows version 3.00 (GraphPad Software) was used for analysis. The null hypothesis of each experiment was that the extract, fraction, or substance does not have an influence on the respective parameter. Effects were considered statistically significant if $p$ values were $<0.05$.

\section{Supporting Information}

The extraction and fractionation scheme of lime flower is provided as Supporting Information (Fig. 1S).

\section{Contributors' Statement}

Conception and design of work: A. Hake, N. Symma, A. Hensel, M. Düfer. Data collection: A. Hake, S. Esch, N. Symma. Analysis and interpretation of the data: A. Hake, S. Esch, N. Symma, A. Hensel, M. Düfer. Statistical analysis: A. Hake, S. Esch, N. Symma. Drafting the manuscript: A. Hake, S. Esch, N. Symma, A. Hensel, M. Düfer. Critical revision of the manuscript: A. Hensel, M. Düfer.

\section{Conflict of Interest}

The authors declare the following competing financial interest: The compounds described here in this study have been recorded for patent application, European Patent Application EP 20193376.9 , August 28, 2020. 


\section{References}

[1] Commitee on Herbal Medicinal Products. HMPC assessment report Tiliae flos - Assessment report on Tilia cordata MILLER, Tilia platyphyllos SCOP., Tilia $x$ vulgaris HEYNE or their mixtures, flos. EMA/HMPC/337067. Accessed February 2, 2021 at: https://www.ema.europa.eu/en/ medicines/herbal/tiliae-flos

[2] Council of Europe - European Directorate for the Quality of Medicines. European Pharmacopoiea 10.0: Lime Flower - Tiliae flos. Stuttgart, Germany: Deutscher Apotheker Verlag; 2020

[3] Viola H, Wolfman C, Levi de Stein M, Wasowski C, Peña C, Medina JH. Isolation of pharmacologically active benzodiazepine receptor ligands from Tilia tomentosa (Tiliaceae). J Ethnopharmacol 1994; 44: 47-53

[4] Cavadas C, Fontes Ribeiro CA, Santos MS, Cunha AP, Macedo T, Caramona MM, Cotrim MD. In vitro study of the interaction of Tilia europaea $\mathrm{L}$. aqueous extract with $\mathrm{GABA}_{\mathrm{A}}$ receptors in rat brain. Phytother Res 1997; 11: 17-21

[5] Aguirre-Hernández E, Rosas-Acevedo $\mathrm{H}$, Soto-Hernández M, Martinez AL, Moreno J, González-Trujano ME. Bioactivity-guided isolation of betasitosterol and some fatty acids as active compounds in the anxiolytic and sedative effects of Tilia americana var. mexicana. Planta Med 2007; 73: 1148-1155

[6] Cotrim MD, Figueiredo IV, Cavadas C, Cunha A, Proença da Cunha A, Caramona MM, Macedo TRA. Pharmacological properties of Tilia europaea aqueous extract: Screening anxiolytic/sedative activity in mice. Arq Patol 1999; 31: 23-29

[7] Reinboth M, Wolffram S, Abraham G, Ungemach FR, Cermak R. Oral bioavailability of quercetin from different quercetin glycosides in dogs. Br J Nutr 2010; 104: 198-203

[8] Cotrim MD, Figueiredo IV, Cavadas C, Fontes Ribeiro CA, Isabel PJ, Proença da Cunha A, Caramona MM, Macedo TRA. Effects of Tilia europae on guinea-pig ileum and aorta: abstract. Br J Pharmacol 1994; 114: 287

[9] Al-Essa MK, Mohammed FI, Shafagoj YA, Afifi FU. Studies on the direct effects of the alcohol extract of Tilia cordata on dispersed intestinal smooth muscle cells of guinea pig. Pharm Biol 2007; 45: 246-250

[10] Schmidgall J, Schnetz E, Hensel A. Evidence for bioadhesive effects of polysaccharides and polysaccharide-containing herbs in an ex vivo bioadhesion assay on buccal membranes. Planta Med 2000; 66: 48-53

[11] Kram G, Franz G. Untersuchungen über die Schleimpolysaccharide aus Lindenblüten. [Analysis of linden flower mucilage.] Planta Med 1983; 49: $149-153$

[12] Karioti A, Chiarabini L, Alachkar A, Fawaz Chehna M, Vincieri FF, Bilia AR. HPLC-DAD and HPLC-ESI-MS analyses of Tiliae flos and its preparations. J Pharm Biomed Anal 2014; 100: 205-214

[13] Negri G, Santi D, Tabach R. Flavonol glycosides found in hydroethanolic extracts from Tilia cordata, a species utilized as anxiolytics. Rev Bras PI Med 2013; 15: 217-224

[14] Toker G, Baser KHC, Kürkçüoglu M, Özek T. The composition of essential oils from Tilia L. species growing in Turkey. J Essent Oil Res 1999; 11: 369-374

[15] Symma N, Sendker J, Petereit F, Hensel A. Multistep analysis of diol-LCESI-HRMS data reveals proanthocyanidin composition of complex plant extracts (PAComics). J Agric Food Chem 2020; 68: 8040-8049

[16] Czerwińska ME, Dudek MK, Pawłowska KA, Pruś A, Ziaja M, Granica S. The influence of procyanidins isolated from small-leaved lime flowers (Tilia cordata MILL.) on human neutrophils. Fitoterapia 2018; 127: 115122

[17] Symma N, Bütergerds $M$, Sendker J, Petereit $F$, Hake A, Düfer $M$, Hensel A. Novel piperidine and 3,4-dihydro-2H-pyrrole alkaloids from Tilia platyphyllos and Tilia cordata flowers. Planta Med 2021. doi:10.1055/a-1340-0099
[18] Farlow M. A clinical overview of cholinesterase inhibitors in Alzheimer's disease. Int Psychogeriatr 2002; 14: 93-126

[19] Porstmann T, Ternynck T, Avrameas S. Quantitation of 5-bromo-2-deoxyuridine incorporation into DNA: an enzyme immunoassay for the assessment of the lymphoid cell proliferative response. J Immunol Methods 1985; 82: 169-179

[20] Oinonen PP, Jokela JK, Hatakka Al, Vuorela PM. Linarin, a selective acetylcholinesterase inhibitor from Mentha arvensis. Fitoterapia 2006; 77: 429-434

[21] Liu J, Peng C, Zhou QM, Guo L, Liu ZH, Xiong L. Alkaloids and flavonoid glycosides from the aerial parts of Leonurus japonicus and their opposite effects on uterine smooth muscle. Phytochemistry 2018; 145: 128-136

[22] Nassenstein C, Wiegand S, Lips KS, Li G, Klein J, Kummer W. Cholinergic activation of the murine trachealis muscle via non-vesicular acetylcholine release involving low-affinity choline transporters. Int Immunopharmacol 2015; 29: 173-180

[23] Freitas TR, Danuello A, Viegas Júnior C, Bolzani VS, Pivatto M. Mass spectrometry for characterization of homologous piperidine alkaloids and their activity as acetylcholinesterase inhibitors. Rapid Commun Mass Spectrom 2018; 32: 1303-1310

[24] Choudhary MI, Nawaz SA, Zaheer-ul-Haq, Azim MK, Ghayur MN, Lodhi MA, Jalil S, Khalid A, Ahmed A, Rode BM, Atta-ur-Rahman, Gilani AU, Ahmad VU. Juliflorine: A potent natural peripheral anionic-site-binding inhibitor of acetylcholinesterase with calcium-channel blocking potential, a leading candidate for Alzheimer's disease therapy. Biochem Biophys Res Commun 2005; 332: 1171-1177

[25] Gao C, Ding Y, Zhong L, Jiang L, Geng C, Yao X, Cao J. Tacrine induces apoptosis through lysosome- and mitochondria-dependent pathway in HepG2 cells. Toxicol In Vitro 2014; 28: 667-674

[26] Shibasaki M, Crandall CG. Effect of local acetylcholinesterase inhibition on sweat rate in humans. J Appl Physiol 2001; 90: 757-762

[27] McCain KR, Sawyer TS, Spiller HA. Evaluation of centrally acting cholinesterase inhibitor exposures in adults. Ann Pharmacother 2007; 41: 16321637

[28] Senapathi TGA, Wiryana M, Subagiartha IM, Suarjaya IPP, Widnyana IMG, Sutawan IBKJ, Jaya AAGPS, Thewidya A. Effectiveness of intramuscular neostigmine to accelerate bladder emptying after spinal anesthesia. Ther Clin Risk Manag 2018; 14: 1685-1689

[29] Farmakidis C, Pasnoor M, Dimachkie MM, Barohn RJ. Treatment of myasthenia gravis. Neurol Clin 2018; 36: 311-337

[30] Lostao MP, Hirayama BA, Loo DD, Wright EM. Phenylglucosides and the $\mathrm{Na}^{+} /$glucose cotransporter (SGLT1): Analysis of interactions. J Membr Biol 1994; 142: 161-170

[31] de Arriba SG, Naser B, Nolte KU. Risk assessment of free hydroquinone derived from Arctostaphylos Uva-ursi folium herbal preparations. Int J Toxicol 2013; 32: 442-453

[32] Mosmann T. Rapid colorimetric assay for cellular growth and survival: Application to proliferation and cytotoxicity assays. ] Immunol Methods 1983; 65: 55-63

[33] Ellman GL, Courtney KD, Andres V, Featherstone RM. A new and rapid colometric determination of acetylcholinesterase activity. Biochem Pharmacol 1961; 7: 88-95

[34] Jabeur I, Martins N, Barros L, Calhelha RC, Vaz J, Achour L, Santos-Buelga C, Ferreira ICFR. Contribution of the phenolic composition to the antioxidant, anti-inflammatory and antitumor potential of Equisetum giganteum L. and Tilia platyphyllos SCOP. Food Funct 2017; 8: 975-984

[35] Szűcs Z, Cziáky Z, Kiss-Szikszai A, Sinka L, Vasas G, Gonda S. Comparative metabolomics of Tilia platyphyllos SCOP. bracts during phenological development. Phytochemistry 2019; 167: 112084

[36] Ziaja M, Pawłowska KA, Józefczyk K, Pruś A, Stefańska J, Granica S. UHPLC-DAD-MS/MS analysis of extracts from linden flowers (Tiliae flos): Differences in the chemical composition between five Tilia species growing in Europe. Ind Crops Prod 2020; 154: 112691 